\title{
A Scottish freedom of information regime for a denationalised environment: rhetorical or authentically practical?
}

\section{FIRST AUTHOR:}

\author{
Calum Liddle
}

AFFILIATION: PhD Researcher in the Department of Computer and Information Sciences at the University of Strathclyde

ADDRESS: University of Strathclyde, Livingstone Tower, Room 1207, 26 Richmond Street, Glasgow, G1 1XH

telephone: 01415483583

email: calum.liddle@strath.ac.uk

\section{SECOND AUTHOR:}

David McMenemy

AFFILIATION: Lecturer in the Department of Computer and Information Sciences at the University of Strathclyde

ADDRESS: University of Strathclyde, Livingstone Tower, Room 1420, 26 Richmond Street, Glasgow, G1 1XH

telephone: 01415483045

email: d.mcmenemy@strath.ac.uk

\begin{abstract}
ABTRACT: This paper provides an evaluation of the Scottish freedom of information regime in the modern denationalised environment. The authors conducted a pragmatic investigation by means of a real-world compliance inquiry which involved, among other things, the electronic submission of standardised requests for information to those local authority arm's-length external organisations which find themselves now subject to the provisions of the Freedom of Information (Scotland) Act 2002. A compliance matrix, with several response measures, recorded the progression and outcome of the requests sent to each named 'public authority'. The article is also furnished with a contextual overview of the interaction between the home nation FOI regimes and private enterprise with a nod to contemporaneous events. In turn, the paper reveals several quagmires for the operational practicality of FOI in the privatised arena: a pronounced reminder of the difficulties associated with maintaining a functioning and practical FOI regime in light of a myriad of public service delivery models in the denationalised epoch.
\end{abstract}

KEYWORDS: freedom of information, transparency, privatisation, Scotland

ACKOWLEDGEMENTS: This work was supported by a grant from the Arts and Humanities Research Council for which the authors and the Department of Computer and Information Sciences at the University of Strathclyde are grateful. 


\section{A Scottish freedom of information regime for a denationalised environment: rhetorical or authentically practical?}

\section{Introduction}

This year marks the tenth anniversary since Scotland's freedom of information regime came into force. The Freedom of Information (Scotland) Act 2002 is widely acknowledged and praised for its perceived strengths over the United Kingdom's counterpart, namely, the Freedom of Information Act 2000. ${ }^{1}$ One alleged strength is the recent extension made to the scope of FOI in Scotland: the Designation of Persons as Scottish Public Authorities Order 2013 (the '2013 Order') extended the regime's scope to include those local authority arm'slength organisations ('ALEOs') which provide culture and leisure services. The 2013 Order, enforced since April 2014, responds directly to flux and change in the public service delivery landscape: the rights guaranteed by freedom of information are protected by the 2013 Order, where they would otherwise have been lost, when specific public functions are outsourced by a public authority. The 2013 Order looked to, in no uncertain terms, protect an applicant's information rights from the erosion to FOI caused, incidentally, by privatisation. ${ }^{2}$ The Scottish regime might, therefore, sit contrary to the shrinking scope of UK FOI which, for one, has no equivalent Order and, in particular, has been hampered in light of an accelerated programme of denationalisation in the course of the last Westminster parliamentary term.

Praising the revised scope of the Scottish FOI regime as a result of the 2013 Order might, however, be too simplistic in concluding that Scotland's regime is, therefore, strengthened by default. Such a conclusion fails to evidence whether or not the extension, in actual fact, functions properly in real-world practice; that which is merely rhetorical ought now, surely, to be sifted from that which is authentically practical. There is, as yet, no case law or evidence concerned with the newly designated public authorities and the right to information. ${ }^{3}$ As such there is a distinct paucity in any research: Are ALEOs complying with their newly assumed FOI responsibilities? And might indeed, therefore, the parallel rights afforded to applicants employing the United Kingdom FOI regime be distinctly weaker in comparison to those in Scotland, as a result?

The article is first furnished with a contextual overview of the interaction between private enterprise and the home nation freedom of information regimes with relevant statutory analysis and a nod, of course, to contemporaneous events. This paper thereafter constitutes a pragmatic investigation by means of a real-world compliance inquiry. Standardised requests for information were electronically submitted to 25 named ALEOs in order to determine whether the extension of the FOI law in Scotland is operating in practice, as intended. A compliance matrix, with several response measures, recorded the progression and outcome of the requests sent to each named public authority. The authors sought both informal resolutions and statutory decision notices from the Office of the Scottish Information Commissioner. Comprehensive searches of each ALEO website were also conducted so to determine whether or not the statutory publication scheme, under the terms of FOISA 2002, had been made available for inspection.

To this extent the article provides the first academic account of the extended Scottish FOI regime in the modern denationalised environment and, in turn, identifies a significant amount of ALEOs which are failing to comply with their newly assumed statutory obligations. This paper reveals several quagmires for FOI in the denationalised arena in which, for example, only foreign state owned companies, as opposed to domestic private enterprise, engaged in 
the provision of home nation public service functions are subject to freedom of information. While the intention of extending the scope of the Scottish FOI regime is sound, in working practice the extension, in this instance, does not merit commendation: rate-payers throughout Scotland's 32 council districts are, in actual fact, now participant to a postcode lottery. The findings are a pronounced reminder of the difficulties associated with maintaining a functioning FOI regime in light of privatisation and the myriad of public service delivery models this epoch presents.

\section{Designating bodies for the purpose of FOI}

Whether a public service obligation is undertaken by a private enterprise expressly determines whether a company constitutes a 'public authority' for the purposes of either home nation freedom of information regime. It seems appropriate to first highlight the provenance of ALEO inclusion to the Scottish FOI regime and, for the benefit of readers from the other home nations and further afield, the comparative scope of UK FOI in so far as how each might broadly apply to private enterprises engaged in the provision of public services.

Both home nation freedom of information regimes, enacted under FOIA 2000 and FOISA 2002, came into force on New Year's Day in 2005. Scotland's FOI regime provides any person who requests information from a 'Scottish public authority' which holds it the right, subject to conditions, to be provided with the information by the authority. The UK regime, in a similar vein, applies to the public authorities of the other home nations and to UK-wide public authorities, regardless of whether or not they operate in Scotland. Any public authority, to which freedom of information legislation applies, is subject to only one regime. ${ }^{4}$ It is irrespective of whether the information requested relates to reserved or devolved matters.

In Scotland there are five ways in which an organisation is, or might indeed become, subject to the FOI regime: by being listed in Schedule 1 of FOISA 2002; by being added to Schedule 1 by another Act of the Scottish Parliament; by being added to Schedule 1 under an Order made by the Ministers under Section 4 of FOISA 2002; by an Order made by the Ministers under Section 5 of FOISA 2002 to designate an organisation 'as a Scottish public authority for the purposes of [the] Act'; and, finally, by being a 'publicly-owned company'. Designation for the purposes of the UK FOI regime is near-identical in the parallel sections within FOIA 2000. There is also power to add private bodies to the coverage of FOIA $2000 .^{6}$ The designation process is, in all the circumstances, broadly the same on both sides of the border. The narrative is a parallel one.

The enlarged scope of the Scottish FOI regime came about as a result of a Section 5 Order. The 2013 Order does not list specific bodies like Schedule 1 of FOISA 2002 or, indeed, Schedule 1 of FOIA 2000. The 2013 Order, instead, provides a Schedule which describes the bodies that fall within the scope of the revised Scottish FOI regime. There are two Columns: A person described in Column 1 of the table in the Schedule to the Order is designated as a Scottish public authority in relation to any function of a public nature exercised by it specified in Column 2 of that table.

By virtue of Column 1 a body which has been established or created solely by one or more local authorities who on behalf of any of those authorities developed and/or deliver recreational, sporting, cultural or social functions and activities, and are wholly or partially funded by any of those authorities, is subject to FOISA 2002. The relevant functions to which 
the designation applies are to those functions involving tourism related activities, the provision of public libraries, museums and art galleries, recreational, sporting, cultural and social facilities, and functions and activities advancing well-being. The 2013 Order extends the coverage of FOISA 2002 to a wealth of organisations with very different constitutions: for example, the 2013 Order brings within the scope limited companies, trusts and charities.

The extension of freedom of information obligations to the private sector is not an altogether alien concept to British enterprise. Nor is it a mere novelty, a result or consequence of, for example, accelerated denationalisation in the last Westminster parliamentary term. Supermarkets such as Tesco, Sainsbury's and Asda, in respect to their provision of NHS pharmaceutical services constitute public authorities for the purposes of both home nation FOI regimes. And this has been the case since the enforcement of the home nation regimes since 2005. The UK regime, for example, at section 3(1) of FOIA 2000, states that: 'In this Act "public authority" means [...] any body [...] which is listed in Schedule 1.' Schedule 1, at paragraph 44, goes on: 'Any person providing medical services, general dental services, general ophthalmic services or pharmaceutical services under Part II of the National Health Service Act 1977, in respect of information relating to the provision of these services.'

Private enterprise engagement with the NHS therefore extends itself also to, for example, Boots Opticians, incorporating Dolland \& Aitchison, and the like. Where large businesses, such as those named, are cross-border and, as such, operate under both NHS Scotland, NHS England and/or NHS Wales contracts, the enterprise headquarters, wherever it may be, will find itself dealing with applicants employing two distinct freedom of information regimes and, with it, parallel rights, appeal mechanisms and judicial channels. ${ }^{7}$ Birkinshaw wrote in 2010:

The real breakthrough [for FOI] will occur when private companies performing public functions are designated; when they act, as we say, as "surrogates for the state". Privatisation and off-loading from the public sector to private companies has been a regular feature of governance in the UK for 30 years. The incoming coalition government has voiced its approval of FOIA and has also identified some bodies as suitable for designation, including, for example, a bank that was nationalised in $2007 .^{8}$

The 'breakthrough' failed to materialise on either side of the border. The mechanisms built into either regime, the manner in which organisations become public authorities for the purposes of FOI, are not designed to react to a significant shift in the public service delivery landscape. Designation requires political will. It is a manual process involving the identification of bodies. Privatisation is more often a subtle affair as opposed to an explicit forfeiture of public service obligations by a public authority to a vassal-state-like entity. In the same channel, industries which, for whatever reason, become nationalised, such as the Royal Bank of Scotland, have not, in turn, become subject to FOI. Designation rules are with no universality, nor consistency: a pic ' $n$ ' mix approach is at hand. The Scottish Information Commissioner (the 'SIC'), for example, states that a major contributor to the loss of FOI rights has been the failure to use FOISA 2002 Section 5 powers to designate bodies at a time of rapid change to public service delivery models. The 2013 Order to date is the only under Section 5 in ten years of FOI in Scotland. The author agrees with the SIC that the power has, therefore, been "woefully underused" - especially in light of expressions of political intent which have, to date, failed to materialise. 
Freedom of information is a contemporary to the privatisation of public services: FOI is so easily altered, if not lost altogether, as a consequence of denationalisation. The privatised landscape has not evolved so much and, perhaps, nor so fast since the denationalisation curriculum of Margaret Thatcher. There are some pronounced differences in the public service delivery landscapes north and south of the border; the momentum of privatisation has been different in pace and scale in England and Wales when compared to that which has been undertaken in Scotland. And the comparative rights afforded to applicants under either home nation FOI regime, FOIA 2000 and FOISA 2002, have become distinct as a result of these contrasting policy trajectories. This can be evidenced in observing real-world functions and practice.

\section{The public service delivery landscape and FOI}

\section{Legacy quagmires in the nations and regions of the United Kingdom}

Whether a public service function is undertaken by a designated body or, alternatively, a private enterprise, expressly determines whether there exists a general right to know under either of the home nation freedom of information regimes. Flux and change in the public service delivery landscape, bearing in mind the momentum in denationalisation, impacts upon the extent and scope of the statutory right to know. Rights afforded to applicants under FOISA 2002 might not be shared by applicants employing FOIA 2000 in the event that, for example, a public service has been privatised and falls outside of the UK Act. The political rhetoric concerned with privatisation of course continues, at times, with as much passion now as during the premiership of Mrs Thatcher. For the purposes of this research the narrative is not concerned with this so much, per se. It is, however, incumbent on this paper to provide the background, context and the matters of fact which, today, distinguish the home nation freedom of information regimes from one another as a consequence of the denationalisation curriculum.

Mrs Thatcher's programme of government sought to denationalise the core assets of the old state economy. From 1979 the public service delivery structure was overhauled. The 1983 Conservative manifesto promised to accelerate the privatisation programme in Mrs Thatcher's second term as a foundation to the party's whole economic approach:

If elected we committed ourselves to selling British Telecom, British Airways, substantial parts of British Steel, British Shipbuilders, British Leyland and as many as possible of Britain's airports. The offshore oil interests of British Gas would also be privatised and private capital would be introduced into the National Bus Company. This was an ambitious programme. ${ }^{10}$

Altogether some forty-four major businesses were privatised. ${ }^{11}$ Major, upon his succession, continued the 'battle against socialism' with further privatisation too ${ }^{12}$ and lead the Thatcherite curriculum onwards 'with conviction'. ${ }^{13}$ The legacy of the programme of denationalisation was, of course, largely to United Kingdom public service industries; that is to say, government companies with a remit or obligation to serve all the nations and regions. There were, however, instances in which privatisation was not applied universally to the public service agencies operating in all the nations and regions of the United Kingdom. The 
public service delivery landscape, as a result, now demonstrates some pronounced differences in Scotland in contrast to other parts of the UK.

The nine English water companies and Welsh Water were floated in 1989. Whether with respect to constitutional sensitivities or as a result of a loud Scottish opposition, full water privatisation, in any event, was rejected for Scotland by the Thatcher government. Scotland was an exception to Thatcher's application:

Much emotive nonsense was talked along the lines of, "Look, she's even privatising the rain which falls from the heavens." I used to retort that the rain may come from the Almighty but he did not send the pipes, plumbing and engineering to go with it. ${ }^{14}$

The decision was divisive. Where England's water companies were sold, Scotland's remained in full public ownership. The governance of former public service enterprises in England is contrast to Scotland - at least in parts. What is key is an appreciation of the timeline: privatisation from yesteryears has had momentous but unintended consequences to the coming statutory right to information, enforced form 2005, and its operational scope and practicality. Scottish Water is a public authority subject to the terms and provisions of Scotland's freedom of information regime; the same cannot be said for English water companies which, by default, fall outside the scope of FOIA 2000. This phenomena is not limited to this instance.

\section{Distinct FOI trajectories between Scotland and the UK}

Privatisation is, of course, firmly back on the British political agenda. Any prospective privatisation now of Scottish Water has been advocated, among others, by the Adam Smith Institute $^{15}$ and the CBI. ${ }^{16}$ There is no major political appetite from within the Scots parliament at Holyrood; only the Scottish Conservatives and Scottish Liberal Democrats now advocate denationalisation. ${ }^{17}$ The Scottish administration, with devolved competence for most public service provisions since 1998, has under the SNP taken a contrary stance to the UK denationalisation curriculum witnessed in the last Westminster Conservative-Liberal parliamentary term. Legacy quagmires exist, of course. But the fault-lines between the parliamentary centres still, today, gives way to a distinct divergence in the scope of either home nation FOI regime.

The Scottish Government took a strong objection to the privatisation, by the British Government, of Royal Mail in 2013. Indeed, the Scottish Government subsequently committed, in the event of a 'Yes' vote on independence in 2014 , to renationalise. ${ }^{18}$ Royal Mail Group is no longer wholly owned by the British Government and, as a result, was removed from the scope of the UK FOI regime. It is no longer, for the purposes of FOIA 2000, a UK 'public authority'. An applicant's right to request information was lost. The loss extended itself to Royal Mail's public service function, namely, the universal postal service obligation, which is still guaranteed by law. ${ }^{19}$ The revived curriculum to denationalise also accelerated the privatisation of, for example, prisons in England and Wales to G4S, Sodexo and Serco; there are now 14 in total, housing 17 per cent of the prison population. ${ }^{20}$ Privatised prisons are, unlike their publicly-run counterparts, without FOI oversight falling, incidentally, outside of the scope of the UK Act. The SNP administration in Edinburgh, meanwhile, committed to no future privatisation since assuming office in $2007 ;^{21}$ publically run prisons will remain subject to FOISA 2002. And so, where there exists devolved competence, the 
privatisation policies north and south of the border result in evidenced contradictions in the comparative operational scope of the home nation FOI regimes.

In terms of where else the devolved administration in Edinburgh has contradicted the United Kingdom denationalisation curriculum, the privatisation of British Waterways, for another, provides a fairly typical narrative. British Waterways was dissolved in July 2012 and its responsibilities were transferred to the Canal and River Trust ('CaRT'). At Paragraph 15 of Schedule 3 to The British Waterways Board (Transfer of Functions) Order 2012, it states:

(1) The Freedom of Information Act 2000 is amended as follows.

(2) In Part 6 of Schedule 1 (other public bodies and offices: general) -

(a) omit the entry relating to the British Waterways Board;

(b) at the appropriate place insert - "Canal \& River Trust, in respect of information held by it relating to functions exercisable by it by virtue of the British Waterways Board (Transfer of Functions) Order 2012 (S.I. 2012/1659)".

The amendment to FOIA 2000 affected by the 2012 Order provided that FOI would apply to information held by CaRT. However, this was only to the extent that the information related to the statutory functions taken over from British Waterways. Some of the functions that were transferred to CaRT were related to obligations under the Transport Act 1962, Highways Act 1980, Channel Tunnel Rail Link Act 1996 and the Planning Act 2008; broadly speaking, these functions comprised those which afforded CaRT the authority to operate and maintain the waterways.

In the decisions of the UK Information Commissioner (the 'IC') since privatisation, he has had to determine whether the information requested relates to any or all of the functions transferred by the 2012 Order: 'He considers that it is a question of fact as to whether the information requested is covered by CaRT for the purposes of the FOIA. ${ }^{22}$ The IC interprets functions as meaning obligations specifically entrusted to a particular public authority via statute, rather than general activities or obligations applying to all public authorities. Typical FOI requests, therefore, such as those for remuneration details, for example, are no longer valid, even if submitted to CaRT with reference to the operating period prior to denationalisation.

Following the UK Government decision that British Waterway's functions and assets in England \& Wales would be transferred to CaRT, Scottish Ministers decided to make no change to the arrangements for the ownership, care and maintenance of the Scottish canals. British Waterways, operating as Scottish Canals, continues on a self-standing basis, without involvement from UK Ministers, in Scotland. ${ }^{23}$ It is a public corporation in the Scottish public sector wholly accountable to Scottish Ministers. As such, it remains, in contrast to CaRT, subject to freedom of information. The rights afforded to applicants under FOISA 2002 are not, therefore, necessarily shared with those applicants whom, let's say seek analogous information relating to a synonymous public service function, under the terms of FOIA 2000. The applicant under FOISA 2002 is at a distinct advantage.

Scotland, however, is not of course immune from privatisation and the incidental consequences, as a result, to the operational practicality of its own national FOI regime. Social housing was traditionally administered by local authorities and, since 2005, subject to FOI as an explicit local authority function. During Thatcher's third term, attempts to devolve 
housing stock to private enterprise and the third sector was prevented by judicial intervention. ${ }^{24}$ This element of the reform curriculum has, however, been achieved in the last decade by local authorities on their own accord: social housing is now, largely, administered in Scotland by housing associations. Associations constitute a broad spectrum of enterprises: trusts, charities and private limited companies. As a direct result of the transfer of local authority housing stock, information about housing is no longer accessible under FOI to some 15,000 tenants, nor, of course, to the rate-payer or public at large. ${ }^{25}$ The public pound cannot, in this instance and others alike, be followed into the private purse.

\section{Foreign state-owned buy-outs and tendering}

The greatest affinity between the home nation freedom of information regimes is where both regimes extend the right to know to 'any person'; in this respect the Acts are universal and non-discriminatory of citizenship. ${ }^{26}$ In other words: anybody can ask for information from a scheduled public authority. The United States of America, for another, employs a right to 'any person' and, as such, in this respect there is a three-way trans-Atlantic scope afforded to applicants employing UK and Scottish FOI law. ${ }^{27}$ This is not the norm in respect of the international experience: the newcomers such as Malta, Israel and Jamaica, as well as the impending regime to come into force on the home nation Isle of Man, to name but a few, contain citizenship or residency requirements. Both Scotland and the UK adopted the revered Swedish model of right to know universalism. Where a foreign state-owned company acquires a British public service enterprise it can, in instances, open an information access route through the proxy of an international freedom of information domain. This is, perhaps, one of the most bizarre anomalies associated with FOI in light of privatisation and has come to be known as the 'Amsterdam proxy'. 28

The Scottish Parliament, as a consequence of the Scotland Act 1998, now has the legislative competence and authority for its train services; this includes a remit for the administration to tender autonomously. In 2014 a ten-year ScotRail tender, the single biggest contract let by the Scottish Government, was won by the Dutch rail operator Abellio. The Abellio parent company is Nederlandse Spoorwegen; it is the Dutch government-owned rail company. Information concerning Scotrail and the wider provision of rail services in Scotland, for example, at least that which is held by Nederlandse Spoorwegan and the relevant Dutch Minister's department, falls within the scope of a foreign freedom of information regime, namely, the Dutch FOI law, Wet Openbaarheid van Bestuur 1991: 'Anyone may apply to an administrative authority or to an agency, service or company carrying out work for which it is accountable to an administrative authority for information contained in documents concerning an administrative matter. ${ }^{29}$

The Dutch FOI provisions are universal but, as with any FOI regime, it is intended, primarily, for domestic users; those whom will seek information about rail services in Scotland are, intuitively enough, the Scots: commuters, tax-payers and the fourth estate. The Dutch FOI regime is universal and, fortunately, the nation's mercantile and multi-lingual heritage perhaps lends itself to making the FOI regime accessible, at least to English-speaking Scots. But elsewhere, and even so, through barriers such as the correspondence channels made available publicly, language and translation where necessary, general legal know-how and rights awareness, trans-border freedom of information, in any event, cannot realistically be promoted. The Amsterdam proxy merely mitigates the hindrance to the scope of FOI where the general right to know would otherwise have been lost altogether should a private 
enterprise, as opposed to a State-owned company, have had won the government tender. This narrative is not irregular in the denationalised environment.

Anomalies in information jurisdiction, it would seem, will be of relevance in coming years when readers bear in mind developments such as, for one, the proposed Transatlantic Trade and Investment Partnership: a deal which primarily looks to cut tariffs and regulatory barriers to trade between the US and EU members, making it easier for companies on both sides of the Atlantic to access each other's markets. Markets extend themselves to the provision of public services, of course.

\section{Research methods}

The SIC does not maintain an exhaustive list of those ALEOs falling within the scope of the Scottish FOI regime; such a list, bearing in mind the drafting of the 2013 Order, does not exist. There is, of course, no mention of 'ALEOs' in the relevant statutes. The term is simply an expression used by Audit Scotland, which audits around 200 Scottish public authorities for the Auditor General and the Accounts Commission, as a means of describing particular types of bodies (but neither does Audit Scotland maintain an exhaustive list). Audit Scotland defines ALEOs as any organisation separate from the local authority but subject to local authority control or influence by way of, for example, sitting on the board of that organisation, or through the council being the main funder or the primary shareholder. Councils in Scotland typically operate between one and four ALEOs, although three councils operate 14 or more. The majority of the 32 Scottish councils operate ALEOs and Audit Scotland estimate that there are, in number, around 130 in total. ${ }^{30}$ A small number of those 130, bearing in mind the limited named functions of a public nature in Column 2 of the 2013 Order, are subject to FOISA 2002. FOISA 2002 determines in the first instance the jurisdiction of the SIC, however, the OSIC disclosed the names of 25 ALEOs to the author it had previously identified for its own purposes in light of the 2013 Order. ${ }^{31}$ The sample size is sound, good perhaps, provided the speculative nature adopted in determining how many ALEOs are subject to FOISA 2002. In receipt of the list from the OSIC, the authors embarked on two pragmatic real-world research methods: an investigative survey of each named authority's website in search for the statutory publication scheme; and, in turn, a standardised request for information submitted to each of the named bodies to test compliance with the newly assumed legal information obligations under FOISA 2002.

\section{Website survey: a search for the publication scheme}

The Scottish FOI regime, just like its UK counterpart, requires Scottish public authorities to produce and maintain a publication scheme. ${ }^{32}$ The requirement now, of course, extends itself to all ALEOs which find themselves within the scope of FOISA 2002. ALEOs are, as such, under a legal obligation to publish the classes of information that they make routinely available; and to tell the public both how to access the information and whether disclosure is subject to a payment.

A publication scheme is, in no uncertain terms, the foundation to the implementation of any FOI compliance framework by a public authority. Each of the named ALEOs was, therefore, subject to a website survey in which a thorough manual search for a dedicated FOI webpage and the publication scheme was undertaken. The authors determined as a result of comprehensive searches whether or not the publication scheme had been made available for inspection. 


\section{Standardised requests: a compliance test}

Standardised requests for information were submitted to 25 named ALEOs in order to determine whether the extension of the FOI law in Scotland was, in actual fact, operating practically and as intended. Each ALEO was emailed, with explicit reference being made to the terms of the general right to know under FOISA 2002, requesting:

[1] Which persons have been allocated responsibility for handling freedom of information requests at the public authority? Please provide the name(s), the capacity/position they hold and their email address.

[2] I am aware that the SIC recently held a briefing/training day(s) for ALEOs, such as yours, falling under the scope of FOISA 2002. Can you please confirm whether an official from your public authority attended, in which capacity they attended, the name of the SIC event attended and all relevant dates?

[3] Since falling within the scope of the Act how many requests for information have been received and dealt with under the terms of FOISA 2002 by the public authority? Please provide a figure for each month since April 2014.

A compliance matrix, with several response measures, recorded the progression and outcome of the requests sent to each named public authority. ALEOs were measured in terms of the number of days in which it took for a response to be provided, bearing in mind, of course, that there is a statutory time limit of 20 working days for each public authority to comply with the request under the terms of FOISA $2002 .{ }^{33}$ Each response, in turn, was analysed for technical compliance with FOISA 2002 ensuring that, in this instance, the information was disclosed or, otherwise, that the particulars of any refusal notice were those required by law. ${ }^{34}$ The authors also relied on both informal resolutions and statutory decision notices from the Office of the Scottish Information Commissioner in order to ensure that each request was brought to its conclusion, ensuring the inferences shared in this paper were drawn from a complete quantitative dataset and compliance matrix.

\section{Findings and discussion}

\section{Anomalies in the revised coverage}

One of the 25 arm's-length organisations, namely, Garthdee Alpine Sports, refused to respond in any manner whatsoever to the author's information request. After approaching the Office of the Scottish Information Commissioner with a view to an application for a statutory decision, it was established by the regulator that Garthdee was founded by Aberdeen City Council not solely, nor exclusively with other local authorities but, instead, with other public authorities. Its founding members include, among others, the University of Aberdeen and Robert Gordon University. On the grounds of a mere technicality, where on the part of Column 1 at point (a) in the revised schedule contained in the 2013 Order, ALEOs established by a local authority with a public authority escape from the scope of FOISA 2002. 
For an ALEO to be captured by the scope of FOISA 2002 the body has to have been, 'established or created solely by one or more local authorities [author's emphasis]'. ${ }^{35}$

This is a significant find otherwise overlooked to date: A local authority and public authority, both parties subject to freedom of information, can create a body, from public funds, in an explicit move to outsource the provision of a public service function which, in turn, thereafter effectively becomes exempt from FOI obligations. Freedom of information rights are becoming fragmented. Constituents and tax-payers from within Scotland's 32 council districts will find divergence in which public functions are subject to FOI between the local authority areas. First, it depends upon whether the public service function is delivered by the council or an ALEO which falls under the scope of the 2013 Order. And, second, in the case of an ALEO, whether its constitution fits the terms of the 2013 Order. Such a find, in light of Garthdee, seems especially disappointing when one bears in mind that Audit Scotland had stressed that local authorities should be attaching transparency conditions to funding arrangements when establishing any ALEO: 'In agreeing funding arrangements, councils should consider conditions for the ALEO that align with their own legal requirements and policies. As a minimum, they should [among other things] address [...] freedom of information. ${ }^{36}$

Garthdee, contrary to the guidance issued to local authorities by Audit Scotland, in all the circumstances, failed to engage with the author in this instance. No arrangement exists between the relevant council and the ALEO which looks to protect the scope of FOI. There was, of course, no breach of FOISA 2002 in this instance. The ALEO is not subject to FOI; but nor is the ALEO, in any case, intending to comply with the spirit of freedom of information. The general right to information is, therefore, being eroded as a result of complex ALEO constitutions and local authority failings - at least in this instance - to maintain, by way of contract, transparency obligations on behalf of the constituent and taxpayer.

The number of test subjects was, in turn, reduced from 25 to 24 in removing Garthdee from the sample group and any further analysis.

\section{Publication schemes lacking}

Section 23 of FOISA 2002 requires each public authority, including those defined by the 2013 Order, to adopt and maintain a publication scheme approved by the Scottish Information Commissioner. The purpose of the publication scheme is to provide access to information that an authority readily makes available, without an applicant having to go through the formal request process within FOISA 2002. ${ }^{37}$ Each publication scheme sets out the classes of information that are published by the authority and, for each class, details the manner in which the information is made available, and whether or not a charge will apply. Section 25(3) of FOISA 2002 creates the presumption that where information is made available in accordance with an authority's publication scheme, it is reasonably accessible, and as such is subject to an absolute exemption from release under the terms set out in Part 1 of FOISA 2002. Instead, the information should be made available under the terms set out in the publication scheme. The UK FOI regime places a near-identical obligation upon English, Welsh, Northern Irish and UK-wide public authorities. ${ }^{38}$

A comprehensive survey of each public authority website established that just 19 from the 24 ALEOs had a dedicated FOI webpage. It followed that of the five that had no FOI webpage, 
neither did they have a publication scheme available for inspection. There was no evidence to suggest that five of the ALEOs had adopted a publication scheme approved by the SIC. The lack of a publication scheme suggests that no FOI strategic planning has been undertaken and, certainly at least, that no compliance framework has been adopted by 20 per cent of the test subjects. The omission of a publication scheme is, in the simplest of terms, a barrier to any prospective applicant.

Just one of the ALEOs has adopted a disclosure $\log ^{39}$ ensuring that responses and disclosures (redacted of personal data), including all substantive material, is thereafter also accessible to the rest of the world for inspection. The adoption of a disclosure log, while indeed in excess of any statutory obligation, is something of a hallmark for best transparency governance. It is something to be congratulated.

\section{Compliance failures}

The study measured two technical compliance indicators, namely: the statutory requirement to respond to the request for information promptly and, in any event, within twenty working days $^{40}$; and, second, that the information was disclosed in full or, otherwise, in respect of any refusal notice ${ }^{41}$ that the statutory particulars of the procedure provided by the authority for dealing with complaints about the handling by it of requests for information, and the rights of application to the Commissioner, were included. ${ }^{42}$

In the 2013/14 reporting period for the Scottish Information Commissioner, 24 per cent of applications for appeal concerned failures by public authorities to respond to requests for information within the statutory time limit, or at all. ${ }^{43}$ It is the view of the Scottish Commissioner that failure to comply within the statutory time limit is not a mere bureaucratic mis-hap. There are consequences to all parties concerned, including an encumbrance to the national interest in transparency:

For Requesters, failure to respond delays, discourages and deters requesters from accessing information they have a legal right to receive. This in turn fosters mistrust in authorities and [...] may also inhibit the ability to exercise other rights. For authorities, delaying or not responding to a request is a poor strategy that may prove extremely costly, both in terms of resources and reputation. For FOI in Scotland, [a failure to respond] undermines confidence in the effectiveness of the right to information regime, and damages the culture of openness and accountability Scotland is working so hard to embed. $^{44}$

The time taken for each individual ALEO to respond measured from one to ninety-nine working days. Four ALEOs failed to comply within the statutory time limit: two were modestly late measuring 26 and 29 working days; a further two ALEOs only complied with the information request following the start of a formal compliance investigation by the Office of the Scottish Information Commissioner. These responses were, during the course of the Commissioner's investigations, provided to the author and, eventually, measured 94 and 99 working days from the date of submission. In conclusion, four from twenty-four, or 16.66 per cent of test subjects, failed to comply within the statutory time limit. This was the first FOI request many of the ALEOs had received; there is scope for systematic procedures to be 
implemented now to prevent future applicants any denial of their statutory, and timely, right to know.

There was just one refusal by an ALEO which, in all the circumstances, was at least technically compliant with the response mechanisms demanded by FOISA 2002 at the internal review stage - no further analysis was undertaken. During the course of the experiment, other ALEOs mis-read the request, responded in a 'business as usual' approach or, simply, provided a half-way response. Six from twenty-four ALEOs in total (one quarter or 25 per cent), as a result, omitted some information requested in response to the author and failed to make a full disclosure. The refusal to disclose information by way of omission was not explicit and so the response provided by those ALEOs did not, for the purposes of section 16 of FOISA 2002, constitute a refusal notice. The information was, simply, missing.

All those ALEOs which neglected to make a full disclosure, by way of omission, failed also to provide particulars explaining an applicant's right to seek a review of the decision. However, where a Scottish public authority purports to provide an applicant all the relevant information it holds (and that alone), it is not obliged to share the authority's complaints procedure with the applicant. To be clear, this is by virtue of the response failing to technically constitute a refusal notice. The author is not suggesting that, in these cases, responses were in anyway underhand in an attempt to hide the right of appeal. Such responses instead look likely, in all the circumstances, to constitute a breach of the general entitlement because of, much rather, a lack of care, attention and know-how in responding to a request under the terms of FOISA 2002. In any event it is an astonishing result: one quarter of all ALEOs tested with the standardised request replied with responses which failed to provide a full disclosure - by way of omission, in turn breaching s 1(1).

Responses which neglect to address a request by way of a full disclosure and, in turn, fail to make any explicit refusal afford a cumbersome situation to any layperson in receipt of such a reply; the applicant is without any rights knowledge and would have to, themselves, search out advice and assistance. And yet the ALEO, in actual fact, has a statutory duty to, so far as it is reasonable to expect it to do so, provide advice and assistance to the applicant who has made the request for information. ${ }^{45}$ The situation is, put plainly, rather silly. The internal administrative culture is an important factor in ensuring that FOI, at the frontline in practice, works. ${ }^{46}$ The Scottish Commissioner believes it is good practice to explain to applicants their rights of appeal under FOISA 2002 in any case, no matter the outcome of a decision - even when an authority purports to be providing a full disclosure. ${ }^{47}$ This seems sensible, especially as the right of appeal is open to an applicant dissatisfied with the way in which a Scottish public authority has dealt with a request for information, in any event, and needs only state a matter which gives rise to dissatisfaction. It seems perfectly reasonable to therefore conclude that ALEOs might, therefore, adopt the response templates of central government agencies which always, in any case, include a standard paragraph detailing the right to review. This would go some way in demonstrating ALEOs, broadly speaking, wish to participate in the FOI regime proactively, complying for one with the duty to provide appropriate advice and assistance.

\section{Research limitations}

It was evident that at least one response did not comply with s 1(4) of FOISA 2002 in that the information disclosed had been created merely as a result of, and for the purposes of 
responding to, the request for information. ${ }^{48}$ Upon receipt of the response to the standardised request the author, in turn, asked the named ALEO in that instance:

FOISA 2002 at $s$ 1(4) provides that information that is held at the time of a request is the information to be disclosed; I suspect that, perhaps, at the time of my request, in actual fact, no person had yet been assigned responsibility for FOI. Should the answer, therefore, to the request at [1] be "no person" or, more accurately, "no information held"? ${ }^{49}$

The ALEO conceded that the true response was that no information was held because no person at the time of the request had, in actual fact, been assigned FOI responsibility. The response was inappropriate at best, misleading at worst. Applicants have a right to information held at the time of the request. In any event the author considered it too burdensome to ask the OSIC to undertake 23 investigations into each named ALEO to determine whether such a technical breach had been replicated elsewhere; it would provide no substantive material for public inspection. The use of the Commissioner's time and taxpayer funds was not necessary; the authors already established, for the purposes of this research, that technical compliance by the ALEOs was poor in places. Any disclaimer would note that it could, in light of s 1(4), perhaps be worse still. Other technical exemptions include that a Scottish public authority must, so far as it is reasonable to expect it to do so, provide advice and assistance to a person who proposes to make, or has made, a request for information to it. ${ }^{50}$ There is also, for example, a statutory time limit attached to any review outcome. $^{51}$ These technicalities, among others, were not measured and, as such, played no part in the findings.

\section{Conclusion}

It seems incredible that a local authority and public authority, both parties subject to freedom of information, can create a body from public funds which is, in turn, itself effectively exempt from FOI. The drafting of the 2013 Order has, plainly speaking, created an environment where mixed-breed ALEOs are escaping former transparency obligations. Normative accountability expectations are being eroded. It is also an environment where only some public service functions, namely those undertaken by ALEOs caught by the 2013 Order, are subject to the general right to know. But no two local authorities are the same: there now exists, as a result, a postcode lottery. Some constituents will find they have a right to information which others, in neighbouring authorities, do not have. Constituents now reside in a landscape of mixed binary FOI rights between Scotland's 32 local authority boundaries. The 2013 Order has, to this extent, failed to provide an authentically practical solution. A definitive list of Section 5 designees seems appropriate, to say the least, in order to establish, oddly enough, transparency in terms of which ALEOs are, in actual fact, covered by FOISA 2002 and which are not.

In any event, compliance attempts by those ALEOs which have assumed FOI obligations are shown to be, in this instance, unsatisfactory: there was no evidence to suggest that five from twenty-four of the ALEOs had adopted a publication scheme approved by the SIC; one in four failed to provide a full disclosure by way of omitting information, thereby breaching the general entitlement; seventeen per cent of bodies breached the statutory time limit for responding; and an approach by the authors to the Scottish Commissioner for a statutory 
decision notice was necessary in two from the twenty-four tested in order to induce a disclosure.

The home nation freedom of information regimes have diverged in real-world operational practicality as a result of legacy issues attached to the denationalisation curriculum: the Thatcher programme to privatise the core assets of the old state economy continues, today, to nurture a fragmentation in public service delivery models among the nations of the United Kingdom. The divergence in the political culture north and south of the border, with an autonomy courageous administration in Edinburgh unwilling to follow in the denationalisation curriculum, only acts to further pronounce the divergence in the scope of comparative home nation FOI rights; that is to say, those rights afforded to applicants employing FOISA 2002 in contrast to those rights afforded to persons employing FOIA 2000. It seems fair to suggest, therefore, that the Scottish freedom of information regime will remain stronger in light of central government resistance to privatisation, at least in part, of those public services which remain publically-owned and, as such, sit still within the ambit of FOISA 2002. The 2013 Order in Scotland was an explicit attempt to help protect and maintain the scope of FOI in light of the outsourcing of public services to ALEOs by local authorities. However, any note of divergence between the home nations in this respect is, put plainly, negligible. The 2013 Order does not present a new or expansive trajectory of revived rights: its limited scope means it is not to be heralded as the solution to safeguarding information rights in the privatised arena. Indeed, it has merely afforded a fragmented rights landscape to applicants across Scotland's 32 local authority areas. The Birkinshaw breakthrough is yet to come. So what now of a home nation solution?

Following the Upper Tribunal's judgment in Fish Legal \& Emily Shirley v Information Commissioner \& Others [2015] UKUT 0052 (AAC), handed down on 20 February 2015, English Water companies are found now to be subject to the sister legislation to FOIA 2000, namely, the Environmental Information Regulations 2004, by virtue of their 'special powers'. Might then a framework for protecting the scope of FOI by means of a public service test be an appropriate mechanism for designation for the UK and/or Scottish regime? The authors share in the opinion of the SIC for a factor based approach in order to identify functions the Scottish Ministers would consider to be 'of a public nature' and, in turn, appropriate for designation. ${ }^{52}$ Alternatively, the statute book does already, in some instances, explicitly identify public service functions and the responsible bodies which might, perhaps, be appropriate for Schedule 1 listing in either home nation Act. The scope for manually adding to Schedule 1 of FOISA 2002 or FOIA 2000 should not be discounted, however, designation needs to be complemented by means other than listing named authorities 'as and when'. The authors agree with the Campaign for Freedom of Information in Scotland which, too, argues that the legislation should cover public service functions rather than public sector bodies. ${ }^{53}$ Applicants work, reside and manoeuvre on a micro-political and personal level in an environment now very different ten years on since enforcement of the home nation FOI regimes. There is now, in turn, scope for a debate to be undertaken expeditiously in this respect: how best to designate for the purposes of freedom of information in light of privatisation and the myriad of public service delivery models this new epoch presents? 


\section{References}

C Liddle and D McMenemy, 'An evaluation of the United Kingdom and Scottish freedom of information regimes: comparative law and realworld practice' (2014) 19 Comms.L. 77; K Dunion, Freedom of Information in Scotland in Practice (DUP, 2011) 438; and, among others, H Brooke, Your Right to Know (Pluto Press, 2007) 22-25.

${ }^{2}$ Office of the Scottish Information Commissioner. FOI 10 years on: Are the right organisations covered? (SIC, 2015) 8 [19].

${ }^{3}$ There is no case law other than that which now exists as a direct result of the pragmatic research undertaken for the purposes of authoring this paper.

${ }^{4}$ See FOIA 2000 sch 1 and FOISA 2002 sch 1.

${ }^{5}$ FOISA 2002 s 3(1)(b).

${ }^{6}$ P Birkinshaw, 'Freedom of information and its impact in the United Kingdom' (2009) 27 GIQ 312.

${ }^{7}$ See eg UK Comr DN FS50465631.

${ }^{8}$ P Birkinshaw, 'Freedom of information and its impact in the United Kingdom' (2009) 27 GIQ 313.

${ }^{9}$ Office of the Scottish Information Commissioner. FOI 10 years on: Are the right organisations covered? (SIC, 2015) 2.

${ }^{10} \mathrm{M}$ Thatcher, Margaret Thatcher: The Autobiography (Harper Press, 2013) 405.

${ }^{11}$ R Harris, The Conservatives: A History (Bantam Press, 2011) 491.

${ }^{12}$ T Bale, The Conservative Party: From Thatcher to Cameron (Polity Press, 2010) 39; and J Major, John Major: The Autobiography (Harper Collins, 2000) 203.

${ }^{13}$ J Major, John Major: The Autobiography (Harper Collins, 2000) 215.

${ }^{14}$ M Thatcher, Margaret Thatcher: The Autobiography (Harper Press, 2013) 623.

${ }^{15}$ N Hawkins, Privatization - Reviving the Momentum (Adam Smith Institute, 2008) 16.

${ }^{16}$ G Robertson, 'Scottish Water will 'stay public', says Finance Secretary John Swinney' BBC Radio Scotland: Good Morning Scotland (Glasgow 28 August 2012) <http://www.bbc.co.uk/news/uk-scotland-19395666> accessed 10 February 2015.

${ }^{17}$ S Carrell, 'Scottish Lib Dems launch manifesto with pledge to create 100,000 jobs' Guardian (London 5 April 2011)

$<$ http://www.theguardian.com/politics/2011/apr/05/scottish-liberal-democrats-manifesto-pledge-jobs> accessed 10 March 2015.

${ }^{18}$ J Cusick, 'Alex Salmond says an independent Scotland would renationalise Royal Mail and scrap bedroom tax' Independent (London 19 October 2013) <http://www.independent.co.uk/news/uk/politics/snpconference-alexsalmond-says-an-independent-scotland-wouldrenationalise-royal-mail-and-scrap-bedroom-tax-8891485.html> accessed 29 January 2015.

${ }^{19}$ Postal Services Act 2011 s 29.

${ }^{20}$ G Grimwood, 'Prisons: The Role of the Private Sector' (House of Commons Library, 2013)

$<\mathrm{http} / /$ www.parliament.uk/business/publications/research/briefing-papers/SN06811/prisons-the-role-of-the-private-sector> accessed 10 January 2015.

${ }^{21}$ H Mulholland, 'Scottish Executive scraps private prison plan' Guardian (London 23 August 2007)

$<$ http://www.theguardian.com/politics/2007/aug/23/scotland.devolution> accessed 10 March 2015.

${ }^{22}$ UK Comr DN FS50515288 [6].

${ }^{23}$ Transport Scotland, Scottish Canals Framework Document (Transport Scotland, 2013) 4 [17].

${ }^{24}$ R Harris, The Conservatives: A History (Bantam Press, 2011) 494

${ }^{25}$ Office of the Scottish Information Commissioner. FOI 10 years on: Are the right organisations covered? (SIC, 2015) 8 [20]. 


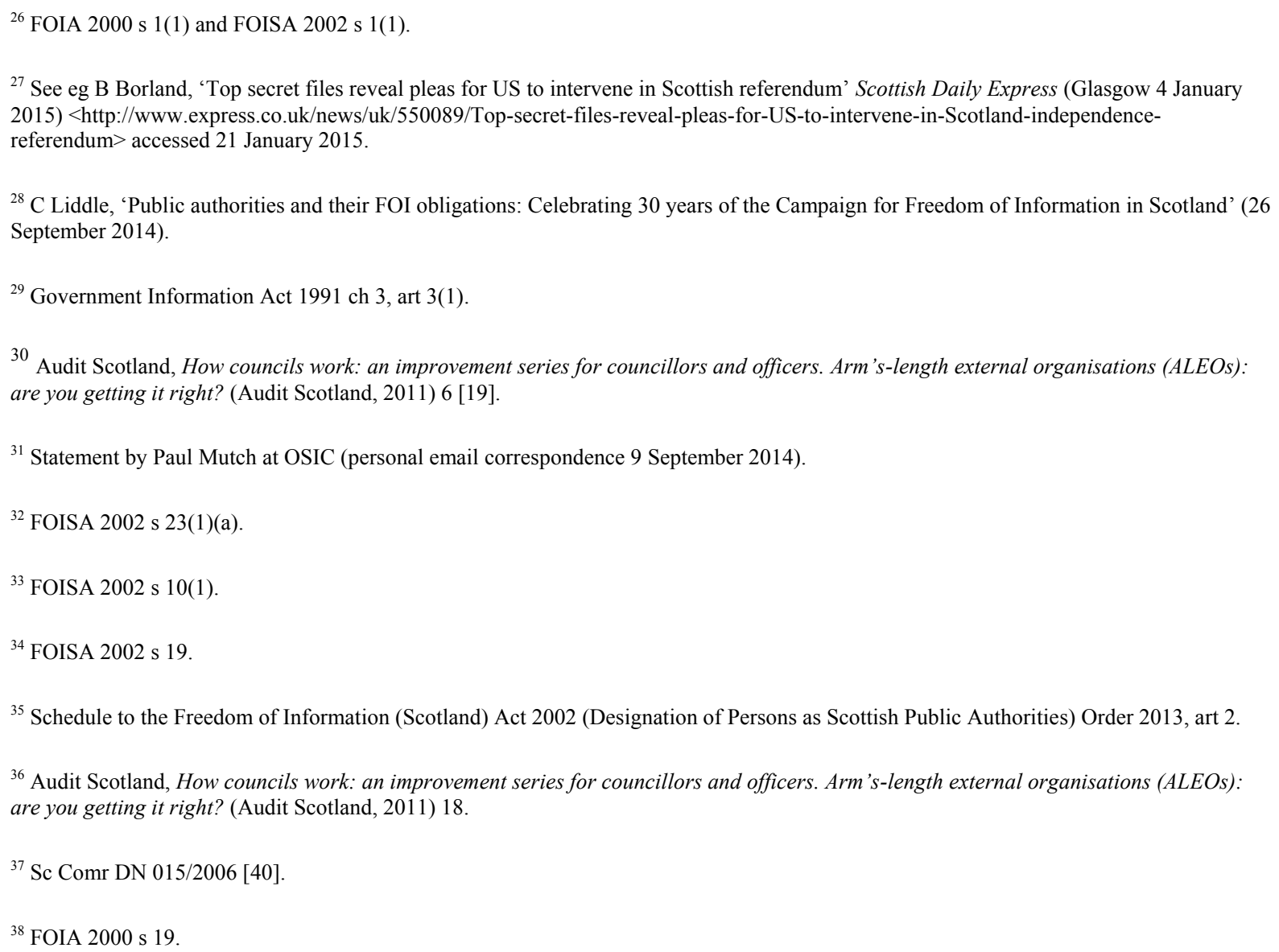

${ }^{28}$ C Liddle, 'Public authorities and their FOI obligations: Celebrating 30 years of the Campaign for Freedom of Information in Scotland' (26 September 2014).

${ }^{29}$ Government Information Act $1991 \mathrm{ch} 3$, art 3(1).

30 Audit Scotland, How councils work: an improvement series for councillors and officers. Arm's-length external organisations (ALEOs): are you getting it right? (Audit Scotland, 2011) 6 [19].

${ }^{31}$ Statement by Paul Mutch at OSIC (personal email correspondence 9 September 2014).

${ }^{32}$ FOISA 2002 s 23(1)(a).

${ }^{33}$ FOISA 2002 s $10(1)$.

${ }^{34}$ FOISA 2002 s 19.

${ }^{35}$ Schedule to the Freedom of Information (Scotland) Act 2002 (Designation of Persons as Scottish Public Authorities) Order 2013 , art 2.

${ }^{36}$ Audit Scotland, How councils work: an improvement series for councillors and officers. Arm 's-length external organisations (ALEOs): are you getting it right? (Audit Scotland, 2011) 18.

${ }^{37}$ Sc Comr DN 015/2006 [40].

${ }^{38}$ FOIA 2000 s 19.

${ }^{39}$ Namely, Caledonia Community Leisure Ltd (trading as Inverness Leisure) $<$ http://www.invernessleisure.co.uk/freedom-of-informationrequests/> accessed 10 April 2015.

${ }^{40}$ FOISA 2002 s $10(1)$.

${ }^{41}$ FOISA 2002 s 16.

${ }^{42}$ FOISA 2002 s 19

${ }^{43}$ Office of the Scottish Information Commissioner, Special Report: Failure to Respond to FOI requests: extent, impact and remedy (SIC, 2014) $3[3]$.

${ }^{44}$ Office of the Scottish Information Commissioner, Special Report: Failure to Respond to FOI requests: extent, impact and remedy (SIC, 2014) $3[4]$.

${ }^{45}$ FOISA 2002, s 15(1).

${ }^{46}$ B Worthy and R Hazell, 'The Impact of the Freedom of Information Act in the UK' in N Bowles, JT Hamilton and DAL Levy (eds), Transparency in Politics and the Media (IB Tauris \& Co, 2014) 40.

${ }^{47}$ Sc Comr DN 004/2014 [18].

${ }^{48}$ The equivalent FOIA 2000 provision can be found at s 1(4).

${ }^{49}$ Research data/correspondence bundle: PKSC. Available from author upon request.

${ }^{50}$ FOISA 2002 s $15(1)$.

${ }^{51}$ FOISA 2002 s 21(1). 
${ }^{52}$ Office of the Scottish Information Commissioner. FOI 10 years on: Are the right organisations covered? (SIC, 2015) 16-19.

${ }^{53} \mathrm{C}$ Bartter, 'FOI also needs to cover housing associations' Scotsman (Edinburgh 18 March 2015) <http://www.scotsman.com/news/foineeds-to-also-cover-housing-associations-1-3720254> accessed 18 March 2015. 